\title{
EVALUATION OF THE HEATING SYSTEM FROM AN INJECTION MOLDING MACHINE
}

\author{
LUMINITA BIBIRE ${ }^{1}$, NARCIS BARSAN ${ }^{*}$ \\ Department of Environmental Engineering and Mechanical Engineering, "Vasile \\ Alecsandri" University of Bacau, Street Marasesti 157, Bacau, Romania
}

\begin{abstract}
Injection is an economical process characterised through an increased productivity that leads, in the majority of cases, to finite pieces. The process of injection includes two distinctive phases, firstly, when the melting occurs, followed by the homogenisation and the creation of pressure; the process takes place in the plasticizing unity; coming next being the second phase that consists in the forming of the producs, in the cavity of the matrix. Regarding the main factors, the purpose of this paper was insuring a thermic regime as uniform as possible in order to obtain an appropriate plastifying process. To do this, with the help of a thermovision camera type Fluke Ti20, the thermic regime has been studied in the area of the plastifying cylinder, following the balancing of the heating resistances.
\end{abstract}

Keywords: heating system, injection molding machine

\section{INTRODUCTION}

Injection is an economical process characterized through an increased productivity that leads, in the majority of cases, to finite pieces. For injection process further processing are not necessary, excepting the removing operation of the casting network. The pieces obtained from injection are also described by an increased level of smoothing surfaces, as well as an acceptable dimensional precision. As examples of finite parts obtained from an injection process it can be mentioned: lids, cans, cogs, bushings, liners and triangles [1-5].

The injection process includes two distinctive phases, firstly, when the melting occurs, followed by the homogenization and the creation of pressure; the process takes place in the plasticizing unity; coming next is the second phase that consists in the forming of the products, in the cavity of the matrix [1-3].

The main factors that determine the quality of the finite parts obtained by using different processes and also injection are: the material used (thermoplastic materials, thermorigid and elastomer), the shape of the finite part, parameters of the injection regime (especially the plasticizing temperature of the material, the pressure and speed of injection). Also, the piece quality and performances after production and/or utilization, depend in many cases on the production parameters monitoring and optimization [1-19].

From the point of view of the plasticizing aggregates, these being, as it has been shown, the main components of the machine, they can be individualized according to Figure 1: injection machines equipped with plasticizing aggregates with screw, this being the case of the studied machine. On the other hand, under the aspect of the mould closing aggregates the following types of actions can be found: mechanical actions, hydraulic actions and hydro-mechanic actions (the case of the bars mechanism actioned with the help of a hydraulic plunger) $[1-3,18]$.

\footnotetext{
* Corresponding author, email: narcis.barsan@ub.ro

(C) 2018 Alma Mater Publishing House
} 
The injection field for a certain material and a certain matrix is delimited by 4 curves, as it can be seen in Figure 2 .

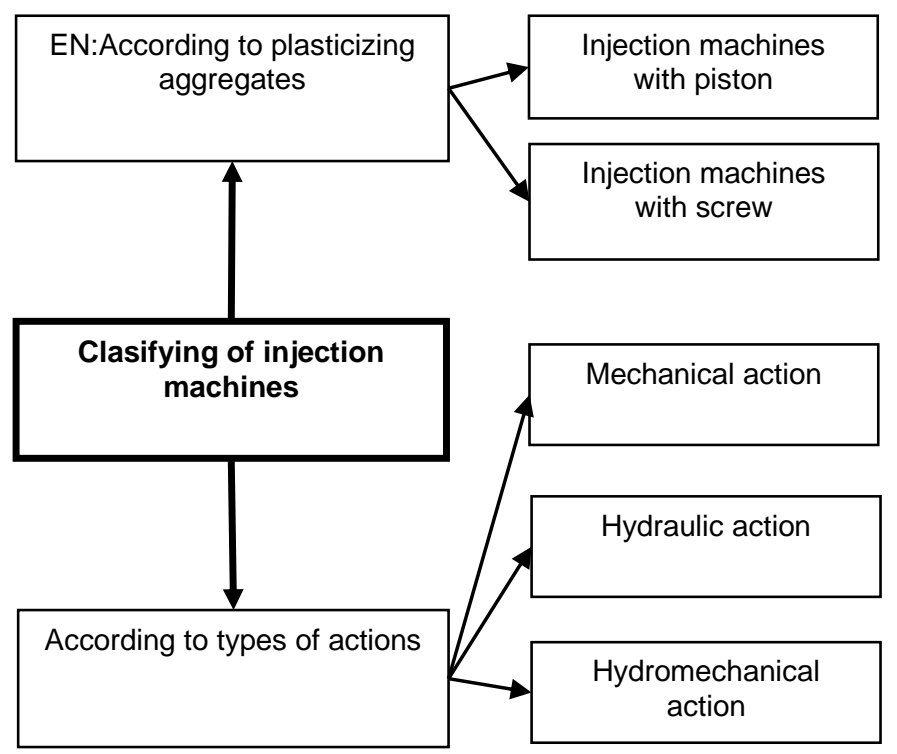

Fig. 1. Classifying of injection machines [1-3, 18].

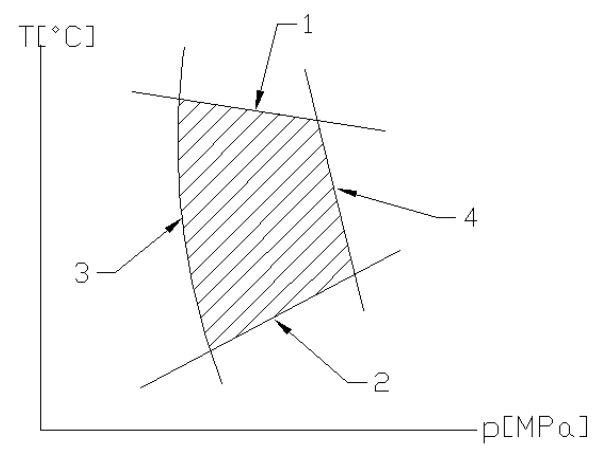

Fig. 2. The curves that delimit the field of injection of the materials [1].

By analyzing Figure 2 it can be noticed that above the curve 1 there is a thermic deterioration of the material and under curve 2 the material is either in a solid state or there is no flow, due to its viscosity that is too high, as a result of the temperatures that were too low. Also, in the left side of the curve noted 3, the mold is incompletely filled, as a result of low values for pressures and/or temperatures. Finally, in the right side of the curve noted 4, the flow of melting between the mold plates starts, as a result of the high pressures and temperatures. [1-3].

Regarding the main factors, the purpose of this paper was insuring a thermic regime as uniform as possible to insure an appropriate plastifying process. To do this, with the help of a thermovision camera type Fluke Ti20, the thermic regime has been studied in the area of the plastifying cylinder, following the balancing of the heating resistances.

\section{EXPERIMENTAL SETUP}

The injection machine studied is composed of two distinctive sub-assemblies such as: the injection aggregate and the aggregate for closing of injection mold, both aggregates being installed on the frame of the injection machine (Figure 3). 


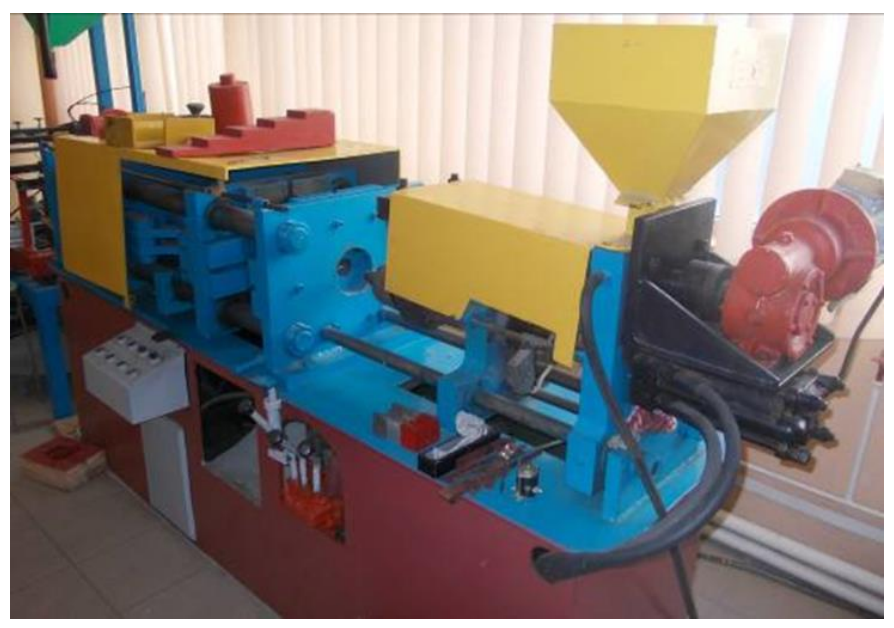

Fig. 3. The studied injection machine for plastics.

Also, the aggregate for injection presents the following component parts: the plastifying cylinder, the snail piston screw and the injection head. On the exterior surface of the plastifying cylinder (barrel), there are the heating resistors and thermocouples, the second having the role of transducers. Although the screw rotates inside the cylinder, this can also be moved as a piston towards the injection head (executing this way a movement of translation specific to the piston mechanisms).

The material that is about to be processed is fed in the feed bunker, where it falls under the effect of gravity in the screw canal. In the feeding area the cylinder is cooled with water through some canals provided through its walls. Regardless of the type of injection machines, these present similar sub-assemblies having the same functions.

The plastifying cylinder (Figure 4) is realized with the interior surface polished to reduce the friction of the polymer. On the exterior surface the heating system can be found that is the main source of heat for the homogenization and softening of the polymer. This is scaled and built so that it lasts at working pressures, temperatures during the process, corrosion and eroding of polymers and the mineral fillings.

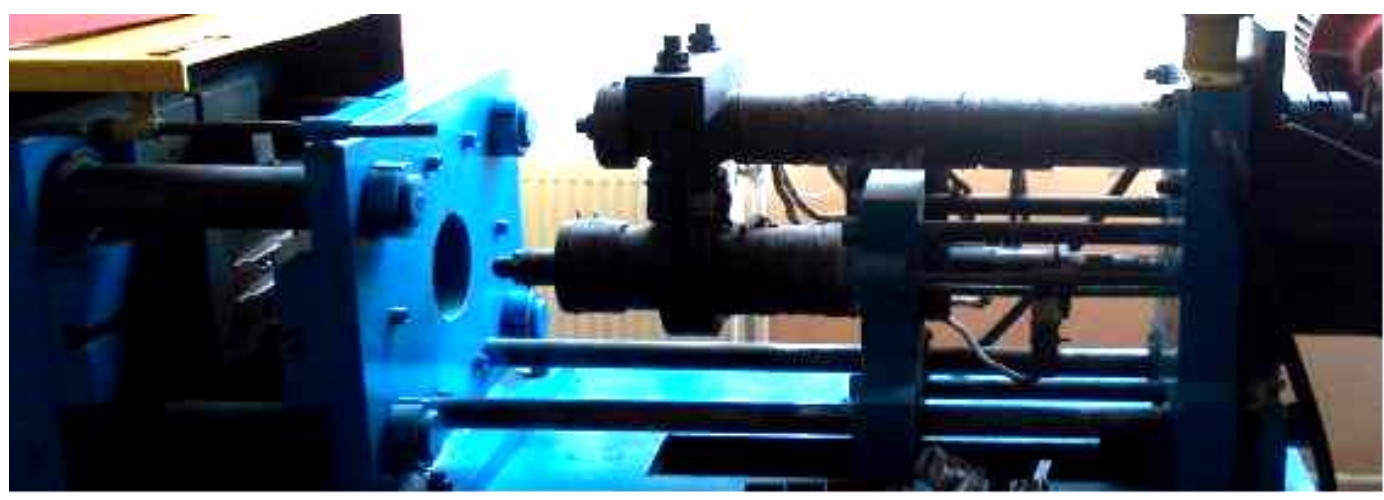

Fig. 4. The plasticizing cylinder of the studied machine.

The heating of the cylinder takes place electrically, by using an electric resistance, which is the most widespread case in practice. These are made like collars that can ease their mounting and dismantling. The electric and thermic isolation of the metallic surfaces of the sleeves is made with micanite, and the sleeves are applied by tightening on the surface of the cylinder without air layers that can reduce the thermic transfer. The images realized with a Fluke Ti20 thermovision camera were transferred using InsideIR software, version 3.11, of which interface is presented in Figure 5. 


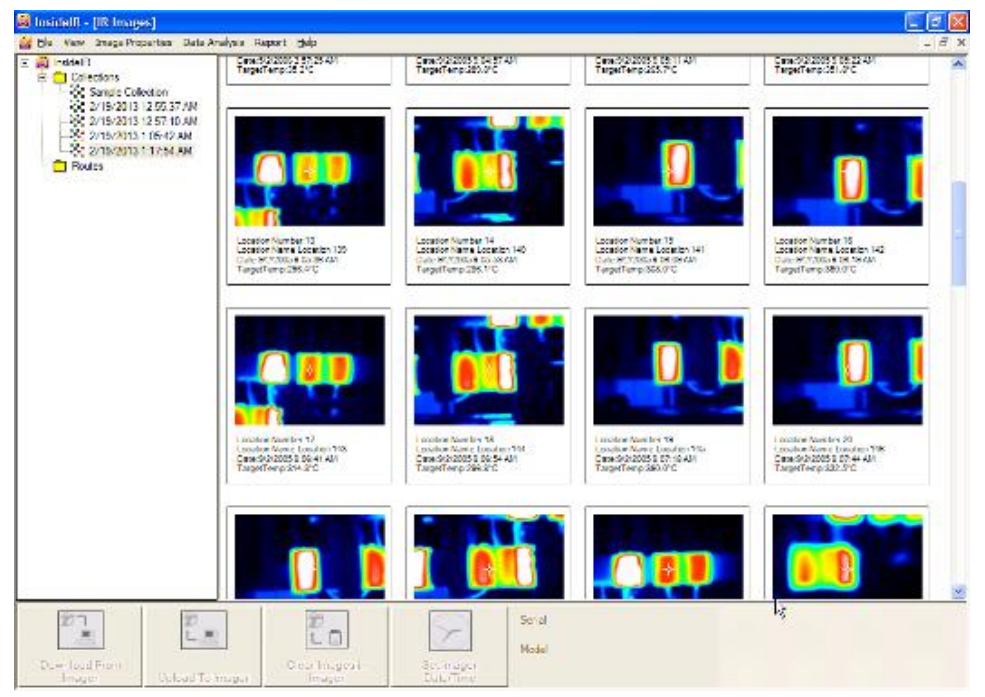

Fig. 5. General view interface of the InsideIR application.

\section{RESULTS AND DISCUSSION}

This study is based on the measurement of the temperature in the interest areas raised by the resistances placed on the surface of the plastifying cylinder, emphasized in Figure 6, reported at the ansamble of the machine, using for this purpose a thermovision camera type Fluke Ti20.

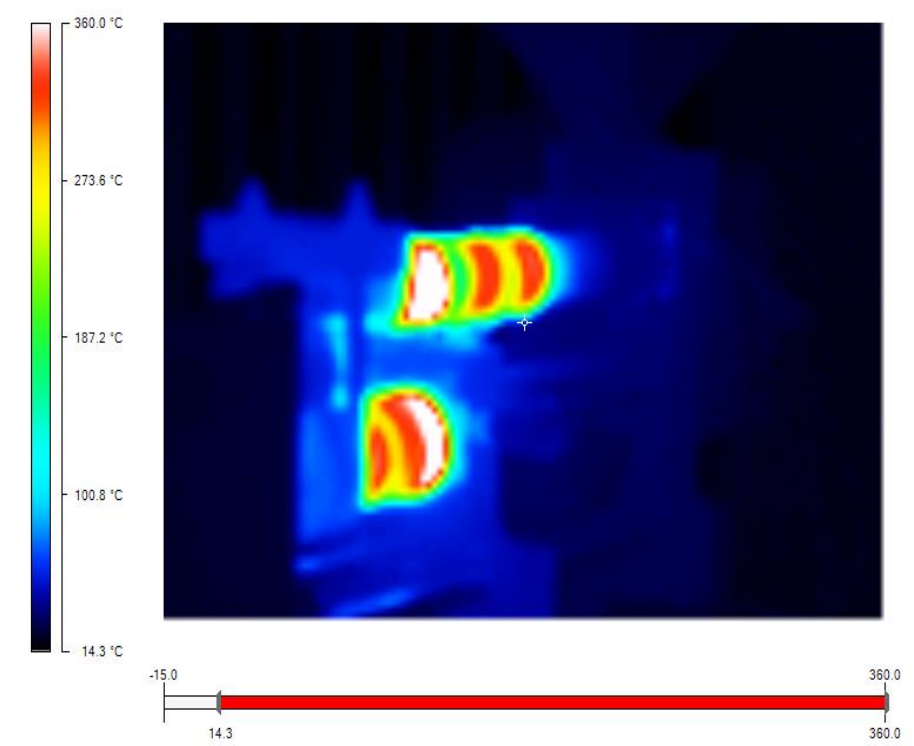

Fig. 6. Emphasizing of interest areas of the injection machine (image obtained with the help of the thermovision camera).

The temperature measurements were performed periodically, at 5 seconds intervals, on each resistance of the injection machine, considering an initial temperature of $20^{\circ} \mathrm{C}$ prior to the resistances turn on. With the help of the InsideIR application-a graph was drawn to show the variation of the temperature along the cylinder on which the resistances were attached.

\subsection{Performing the measurements on the resistances situated in the upper line of the injection machine} Measurements of resistances were realized starting with the three resistances situated in the upper area, on the surface of the plastifying cylinder (indicated in Figures 7 and 8). The order of the measurements starts in the 
upper right area, begining from the resistance from upper left which is the closest to the injection head (in other words the measurements were made from right to the left).

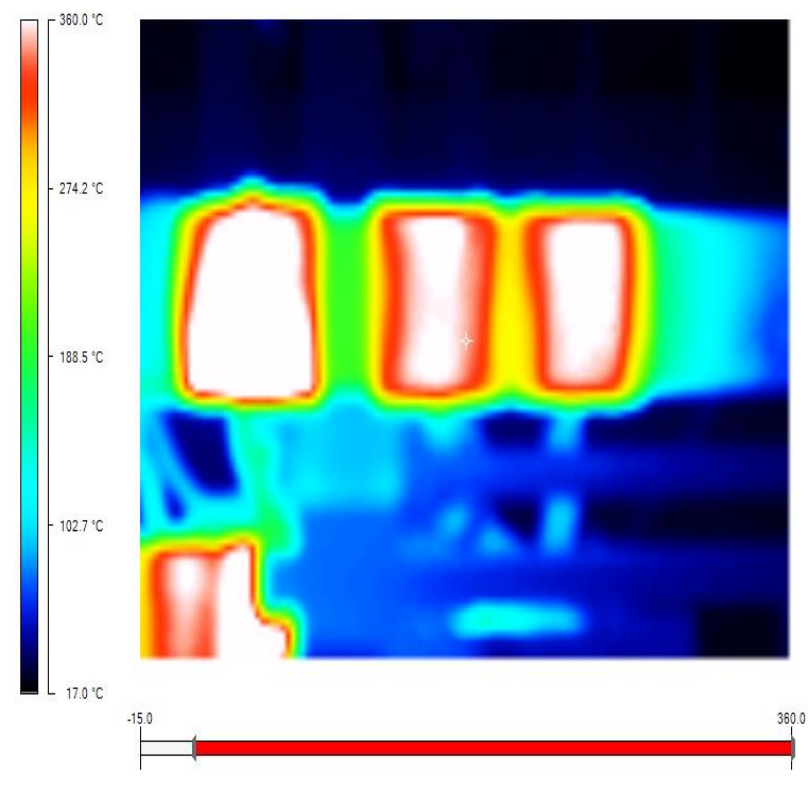

Fig. 7. View over the temperatures distribution on the resistances situated on the surface of the plastifying cylinder (the resistances were turned on, the maximal temperature reaching the value of $360{ }^{\circ} \mathrm{C}$ ).

After approximately 2 minutes from decoupling of the resistances there was emphasized again the distribution of temperatures of the surfaces of the resistances situated on the plastifying cylinder, the maximal temperature being situated at the value of $169.3{ }^{\circ} \mathrm{C}$ according with Figure 8 .

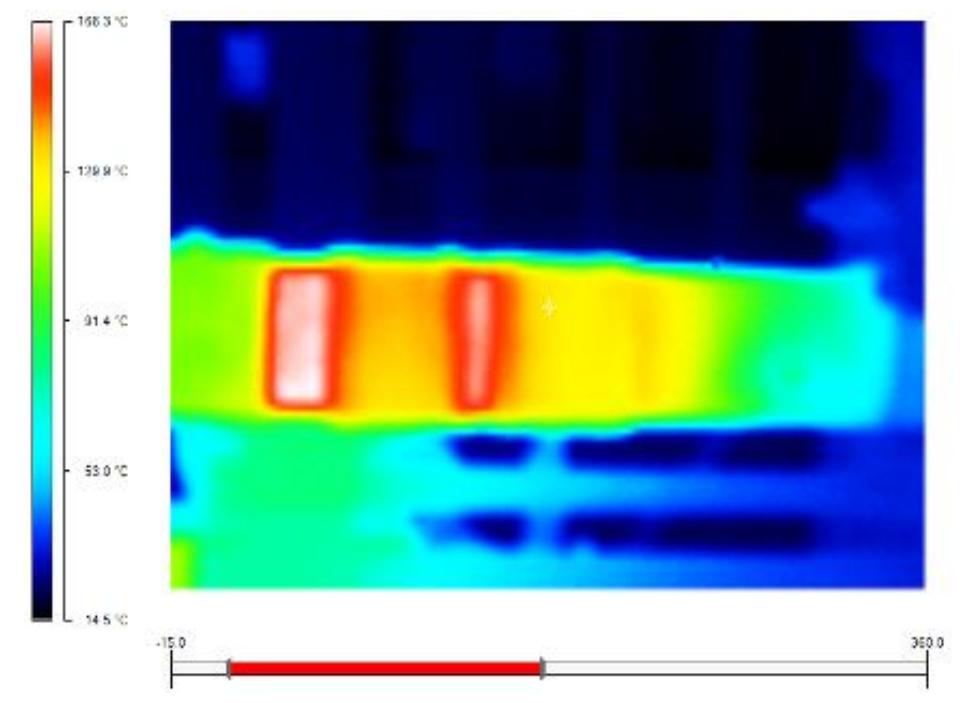

Fig. 8. View over the temperature distribution on the resistances above the surface of the plastifying cylinder, after approximately 2 minutes from decoupling.

For a better identification, each resistance of the injection machine will be attributed with a number of identification, starting from the resistance situated in upper right side until the resistance situated in the lower left (resistances 1, 2, 3 where 1 represents the resistance that is the closest to the feed bunker, and 3 represents the resistance that is the closest to the injection head).

This type of numbering has been chosen in order to correspond to the route of the melt, from the feed bunker to the injection head. 
From analyzing of Figure 9, it can be deducted that although the first two resistances of the injection machine present a variation relatively similar to the temperature in time, the third resistance reached in a shorter time the maximal temperature that can be measured by the thermovision camera and that is $360{ }^{\circ} \mathrm{C}(35 \mathrm{~s}$ compared with the 90 s). This aspect can be also observed in the image presented in Figure 10.

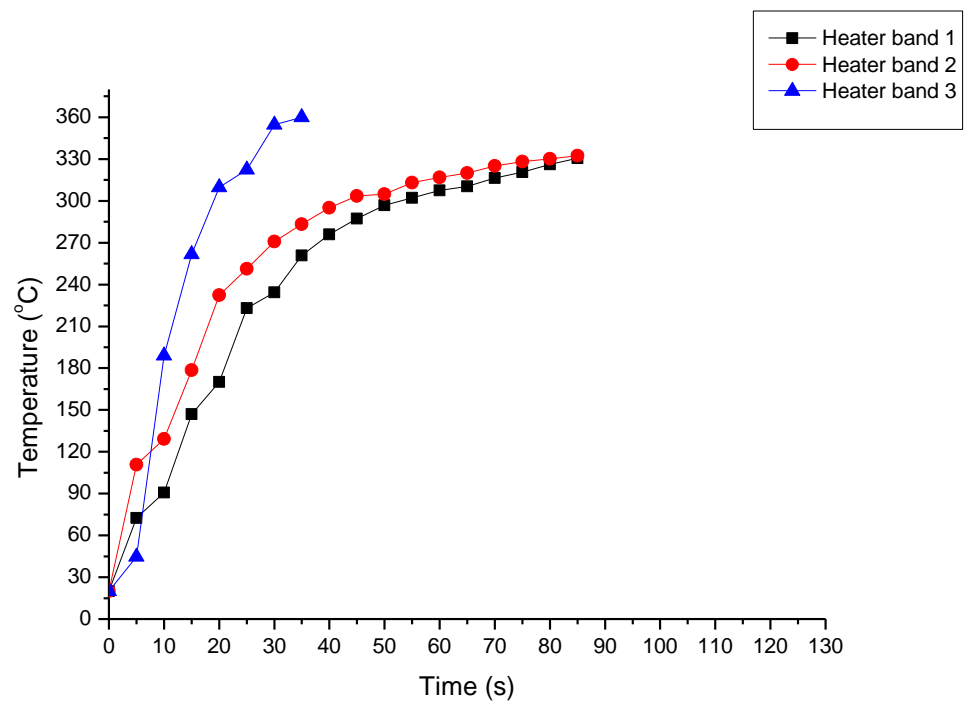

Fig. 9. The variation of the maximal temperature in time, for the resistances 1,2 and 3.

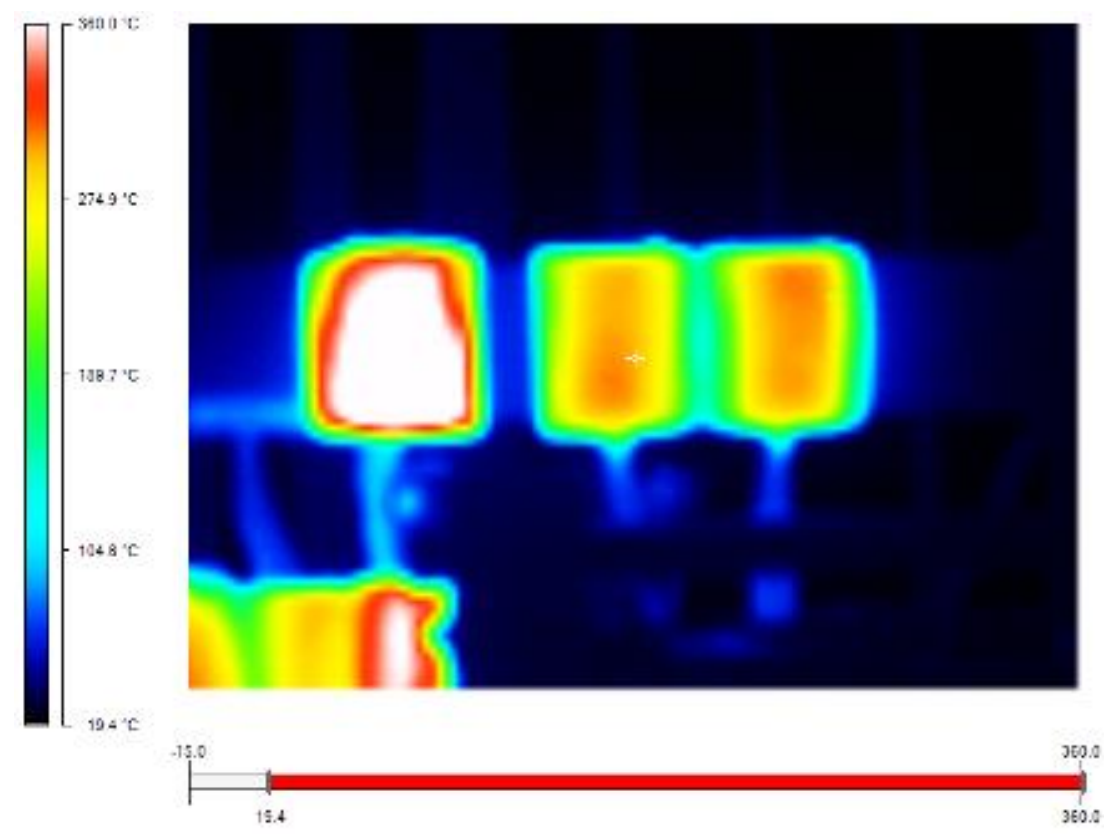

Fig. 10. Image obtained from the thermovision camera that emphasizes the difference in temperature between the third resistance and the other two.

By using the image analysis software recorded it was obtained the repartition of the temperature along the plastifying cylinder, as it can be observed in Figure 11, being called temperature profile. On the Ox axe of the graphic it is represented the length of the plastifying cylinder expressed in millimeters, and on the Oy axe it is represented the value of the temperature, obviously expressed in Celsius degrees. 

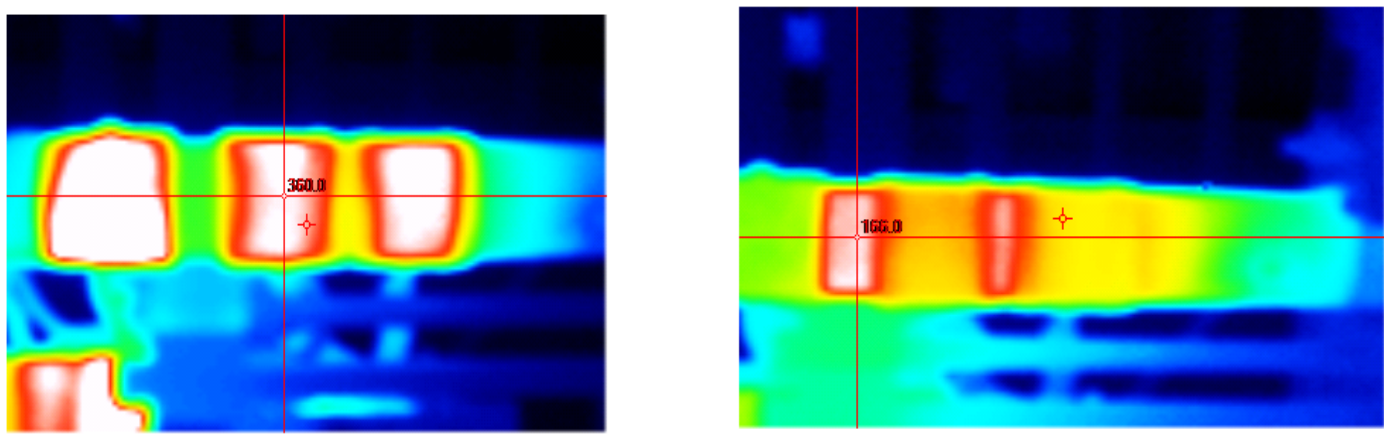

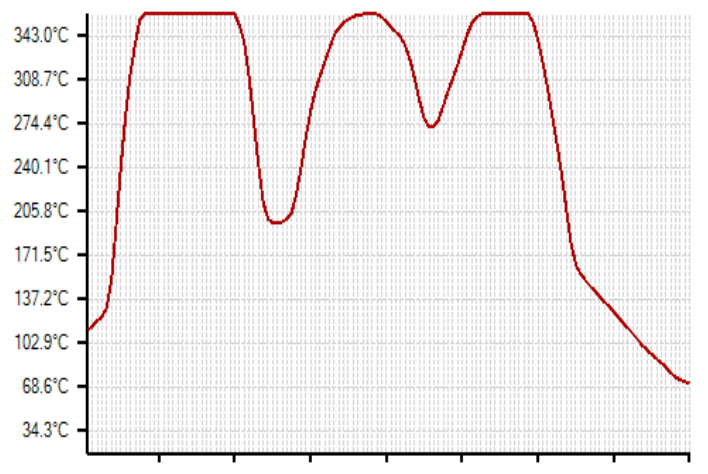

Fig. 11.The temperature distribution along the plastifying cylinder (for the image presented in Figure 7).

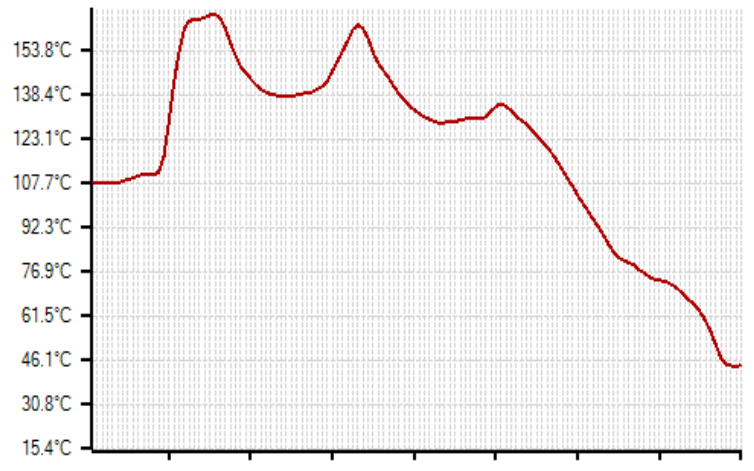

Fig. 12. The temperature distribution along the plastifying cylinder (for the image presented in Figure 8).

Similarly, the distribution of temperature can be obtained along the plastifying cylinder, for the image presented in Figure 8 that is presented in Figure 11.

\subsection{Performing the measurements of resistances situated in the lower row of the injection machine}

Regarding carrying out the measurements required for the resistances in the lower row of the machine, this is realized according to the same rules, the order of measurements starting at this time with the lower right side, starting from the resistance closest to the fuel bunker of the machine and finishing the measurements with the resistance from lower left, which is the closest to the injection head (resistances 4,5 and 6 where 4 represents the closest resistance to the fuel bunker and 6 represents the closest resistance to the injection head).

A view over the distribution of temperatures specific to these resistances is present in Figure 13 (in the turned on state) and Figure 14 (at approximately 2 minutes after decoupling the resistances from the control panel of the machine).

Similar with the first part of the research the maximal temperature variation graph was drawn, against time, keeping the same measurement interval of 5 seconds, Figure 15.

Also with the help of the dedicated software the recorded images were analyzed, by thus generating the temperature variation graphs on the surface of the cylinder. The appearance of the decreased threshold in the graphs in the Figures 16 and 17 it is justified due to the existence of the outrigger that the injection cylinder passes through. 


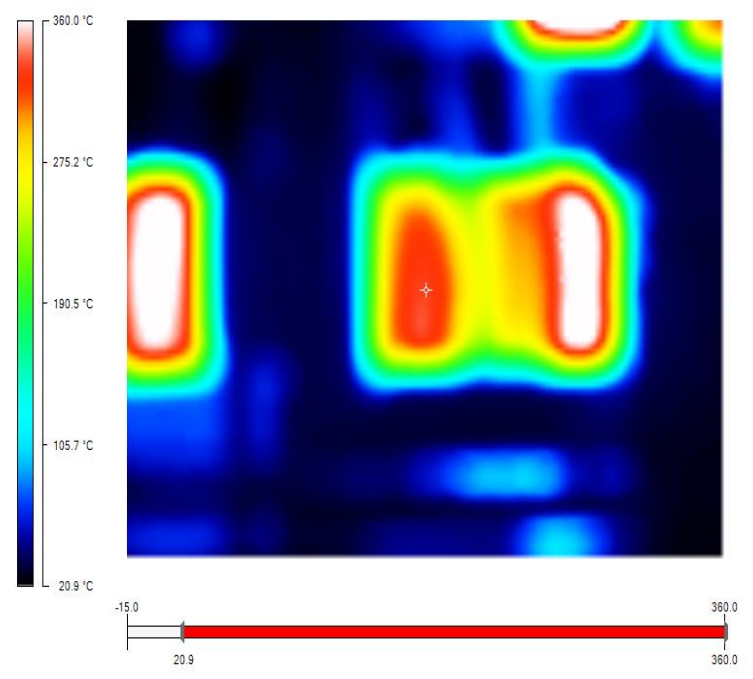

Fig. 13. View over the temperatures distribution on the resistances situated in the lower row of the machine (the resistances were turned on, the maximal temperature reaching the value of $360{ }^{\circ} \mathrm{C}$ ).

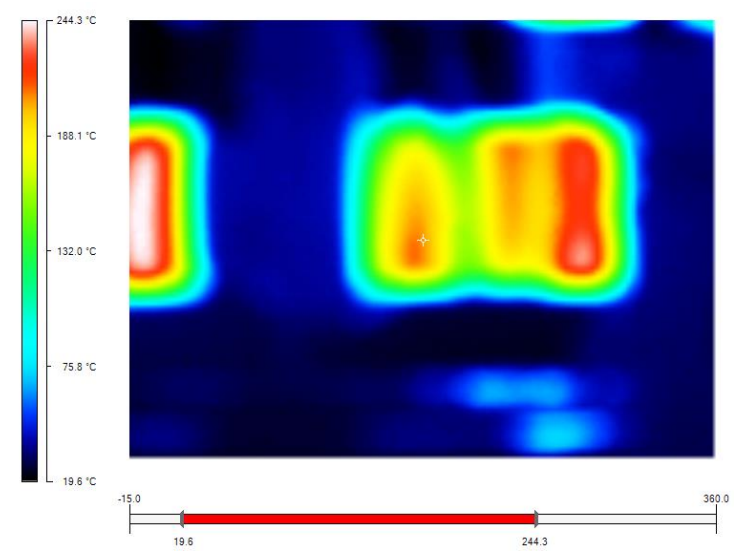

Fig. 14. View over the distribution of temperature in the area of the resistances situated in the lower row of the machine at approximately 2 minutes after the decoupling.

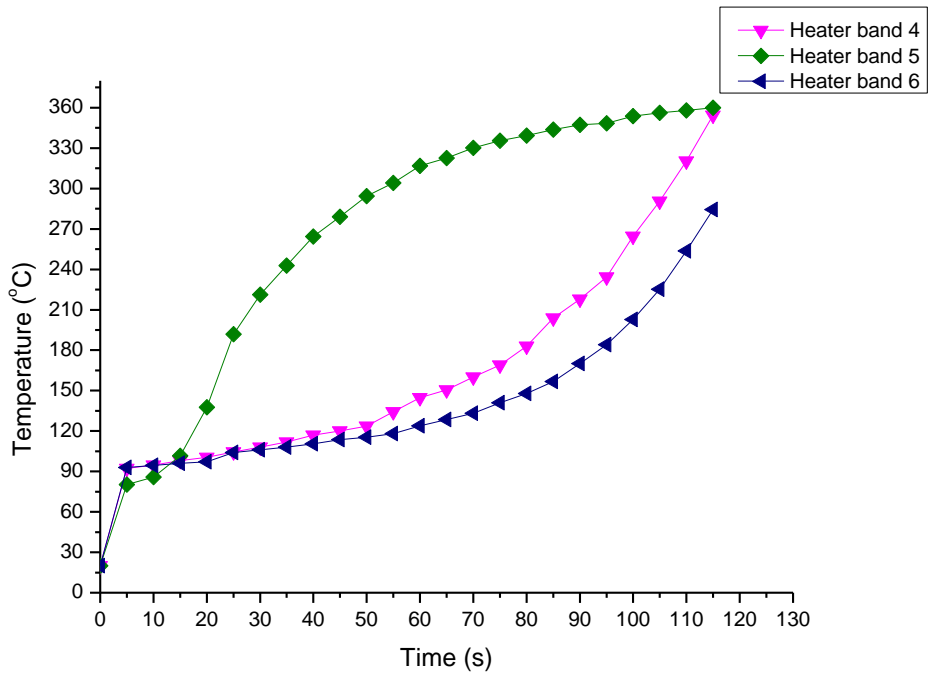

Fig. 15. The maximal temperature variation in time graph, for resistances no. 4, 5 and 6. 

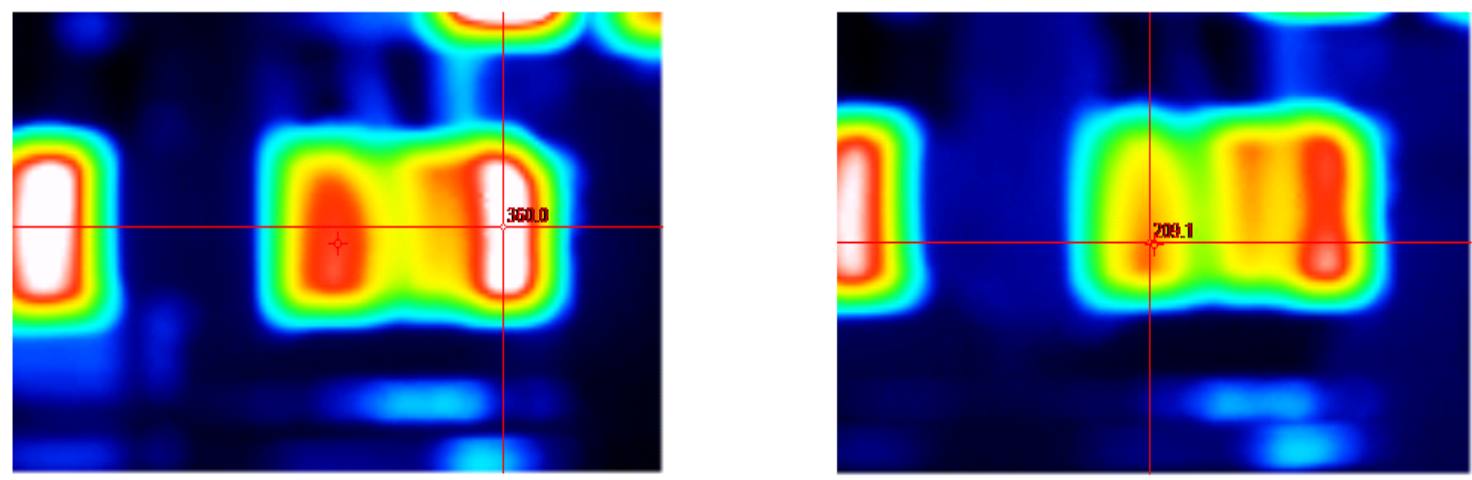

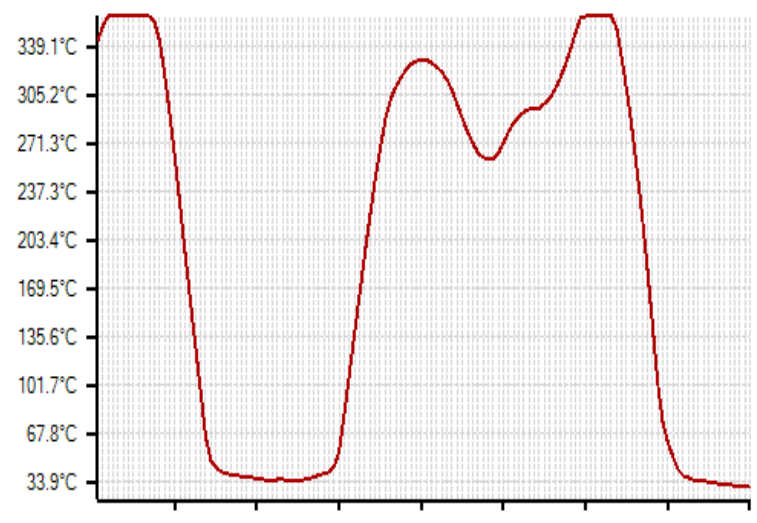

Fig. 16. View over the variation of the temperature on the resistances situated in the lower row of the machine with the resistances turned on (corresponding with the image presented in Figure 13).

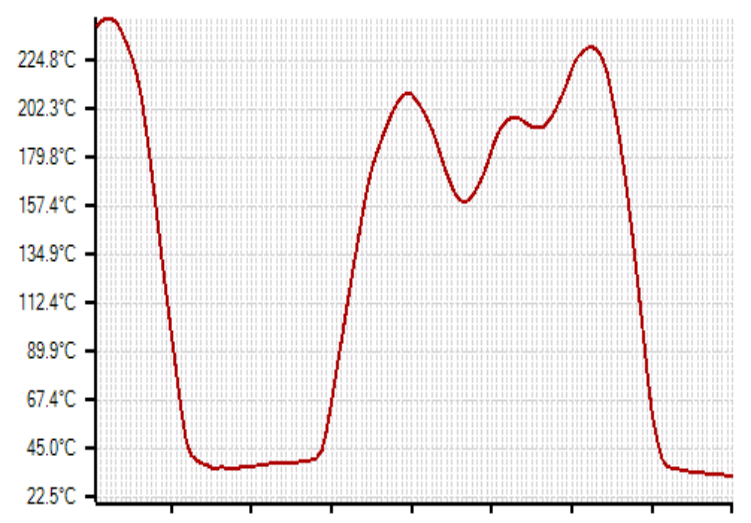

Fig. 17. View over the variation of the temperature on the resistances situated in the lower row of the machine two minutes after turning them off (corresponding with the image presented in Figure 14).

\section{CONCLUSIONS}

According to the objective of this paper, it has been presented an experimental study realized on an injection machine, in which it was measured the variation in time of the maximal temperature (it was named maximal temperature, the temperature indicated by the thermovision camera at the moment of measurement this explanation should be inserted earlier in the paper), being indicated visually, with the help of the images obtained from the thermovision camera, the repartition of the temperatures in the areas of interes, these representing the resistances situated on the surface of the plastifying cylinder (the resistances situated in the upper row of the machine) and the resistances situated on the injection cylinder (the resistances situated in the lower part of the machine). The temperature variation graphs have been drawn along the cylinders on which the resistances were placed, beginning from the moment when they were turned until two minutes after stopping them from the control panel of the machine.

Following this experimental study, it has been found that for the first two resistances, the time to reach the maximal working temperature is higher than in the case of the third resistance, situated at the extremity of the plastifying cylinder (it was obtained in a time shorter by $55 \mathrm{~s}$ ). On the other hand, there can be observed longer times of heating the resistances situated in the lower row of the machine, a possible explanation regarding the mentioned variations being the differences between the nominal value of the resistances indicated in ohms.

In the case of the machined studied, following this study, it was decided to cover the cylinder with a shell of thermic protection (Figure 18). This had as result the reducing with almost $25 \%$ of the electric power use required to heat the cylinder. Also the temperature difference between the lower side and the upper side of the cylinder was reduced because the air circulation is no longer possible. 


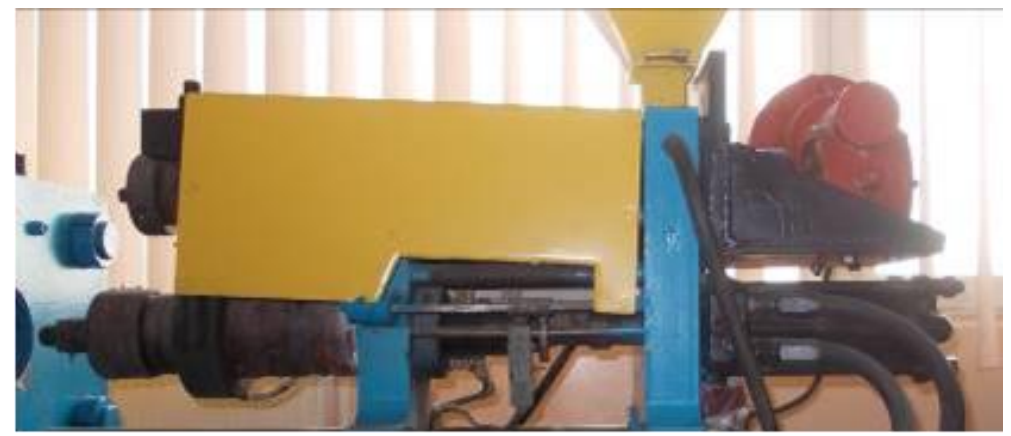

Fig. 18. Covering the plastifying cylinder, with a thermic protection shell.

\section{REFERENCES}

[1] Teodorescu, N., Utilaje şi procedee pentru prelucrarea materialelor polimerice,- curs Universitatea Politehnică Bucureşti, 1993.

[2] Jinescu, V., Mărgean, V., Iatan, R., Oprean, I., Tănase, G., Chiriac, V., Utilajul şi tehnologia constructiilor mecanice - utilaj tehnologic, Editura Didactică şi Pedagogică, Bucureşti, 1988.

[3] Manea, Gh., Prelucrarea prin injecţie a materialelor plastice, Editura Tehnică, Bucureşti, 1988.

[4] Changyu, S., Lixia, W., Qian, L., Optimization of injection molding process parameters using combination of artificial neural network and genetic algorithm method, Journal of Materials Processing Technology, vol.183, no. 2-3, 2007, p. 412-418.

[5] Lo, Y.W., Reible, D.D., Collier, J.R.., Chen, C.H., Three-dimensional modeling of reaction injection molding. II, Application, Polymer Science and Engineering, vol. 34, no. 18, 1994, p. 1401-1405.

[6] Ghenadi, A., Bibire, L., Cobrea, C., Researches Concerning the Initiation and Development of Fracture Cracks in Thermal Fatigue Conditions, Metalurgia International, vol. XIV, no.3, 2009, p. 37.

[7] Ghenadi, A., Silav, C., Obreja, C., Ciclul de viață al produsului, Note de curs, Lucrări de laborator, Îndrumar de proiectare, Editura Alma Mater, Bacău, 2008

[8] Bibire, L., Baze teoretice ale proiectării utilajului tehnologic, Editura Tehnica-Info, Chişinău, 2005.

[9] Bibire, L., Nadabaică, D.C., Fiabilitatea și mentenanța echipamentelor de proces, Alma Mater Bacău, 2014.

[10] Nadabaica, D.C., Radkowski, S., Nedeff, V., Paraschiv, G., Barsan, N., Nicolescu, M.C., Experimental study of noise levels generated by rolling bearings in different stages of deterioration, Environmental Engineering \& Management Journal, vol. 13, no. 7, 2014, p. 1631-1639.

[11] Nadabaica, D.C., Nedeff, V., Bibire, L., Barsan, N., Experimental applications on the influence of internal operation clearance of the faulty rolling bearings upon their remaining lifetime, Journal of Engineering Studies and Research, vol. 20, no. 1, 2014, p. 60-70.

[12] Ştefănescu, M.F., Căderea de presiune la curgerea neizotermă a topiturilor polimerice prin canale, Materiale Plastice, vol. 43, no.3, 2006, p. 254-257.

[13] Ştefănescu, M.F., Răcirea liberă a pieselor formate prin injecţie, Conferinţa "Ingineria Prelucrării Polimerilor", octombrie 2006, Oradea, p.84-88.

[14] Ştefănescu, M.F., Forme de injecţie pentru materiale polimerice. Îndrumar de proiectare, Ed. POLITEHNICA PRESS, Bucureşti, 2012.

[15] Ivascu, N., Fetecau, C., Dynamic temperature control in injection molding with new conformal heating/cooling system, The Annals "Dunărea De Jos" of Galaţi, Techolologies In Machine Building, Fascicle V, 2010, p. 5-9.

[16] http://mechanicalhome.blogspot.ro/2009/12/classification-of-injection-moulding.html (12.02.2018).

[17] Malloy, R.A., Plastic Part Design for Injection Molding An Introduction 2nd Edition, Sample Chapter 5: Prototyping and Experimental Stress Analysis, Hanser Publishers, Munich, Hanser Publications, Cincinnati, 2010.

[18] Rosato, D.V., Rosato, D.V., Rosato, M.G., Injection molding handbook, Springer Science \& Business Media, 2000.

[19] Dubay, R., Self-optimizing MPC of melt temperature in injection moulding, ISA Transactions, vol. 41, no. 1, 2002, p. 81-94. 